\title{
Pathogenic and molecular variability among Brassica isolates of Alternaria brassicae collected from different agro-climatic regions of India
}

Mahesh Singh*1 and H.K. Singh ${ }^{2}$

${ }^{1}$ School of Agriculture Sciences, Galgotias University, Greater Noida (U.P.) India

${ }^{2}$ Department of Plant Pathology, Narendra Deva University of Agriculture and Technology, Kumarganj, Faizabad (U.P.) India

\section{ARITCLE INFO}

Received : 29.08 .2019

Revised : 14.09 .2019

Accepted : 27.09 .2019

KEY WORDS :

Pathogenic, Molecular variability, Alternaria brassicae, Brassica spp.

*Corresponding author:

Email : doctorsingh14@gmail.com

\begin{abstract}
The Alternaria blight is one of the most destructive fungal disease of Indian mustard causes severe damage to the crop. Ten isolates of A. brassicae were collected from various agro-climatic location of India viz., Uttar Pradesh $\left(\mathrm{Ab}_{1}\right)$, Madhya Pradesh $\left(\mathrm{Ab}_{2}\right)$, Uttarakhand $\left(A b_{3}\right)$, Bihar $\left(A b_{4}\right)$, Jharkhand $\left(A b_{5}\right)$, West Bengal $\left(A b_{6}\right)$, Haryana $\left(A b_{7}\right)$, Rajasthan $\left(\mathrm{Ab}_{8}\right)$, Chhattisgarh $\left(\mathrm{Ab}_{9}\right)$ and Gujarat $\left(\mathrm{Ab}_{10}\right)$ and characterized for pathogenic and molecular variations. All the isolates showed high level of variability. The incubation period of the isolates was recorded on $B$. juncea 3 to 4 days, B. carinata 6.17 to 6.83 days, $B$. napus 5.17 to 6.00 days, $B$. nigra 4.17 to 5.17 days and in $B$. campestris it was ranged from 3.17 to 4.00 days. The results revealed that the maximum PDI was noted on Brassica juncea followed by B. campestris var yellow sarson, $B$. nigra, $B$. napus and $B$. carinata. Based on PDI ten isolates could be classified into three groups in which group one consist of isolates $\mathrm{Ab}_{3}, \mathrm{Ab}_{6}, \mathrm{Ab}_{7}$ and $\mathrm{Ab}_{5}$. Isolates $\mathrm{Ab}_{8}, \mathrm{Ab}_{2}$ and $\mathrm{Ab}_{4}$ fall in second group; while group three include isolates $\mathrm{Ab}_{1}, \mathrm{Ab}_{9}$ and $\mathrm{Ab}_{10}$. The dendrogram analysis identified two major clusters with 82 per cent similarity. One cluster (group I) comprised of 3 isolates $\left(\mathrm{Ab}_{1}, \mathrm{Ab}_{10}\right.$ and $\left.\mathrm{Ab} \mathrm{b}_{2}\right)$. Whereas, another cluster (group II) comprised of $\mathrm{Ab}_{3}, \mathrm{Ab}_{6}, \mathrm{Ab}_{7}, \mathrm{Ab}_{5}, \mathrm{Ab}_{4}, \mathrm{Ab}_{8}$ and $\mathrm{Ab}_{9}$ at 86 per cent similarity. The three isolates $\left(\mathrm{Ab}_{3}, \mathrm{Ab}_{6}\right.$ and $\left.\mathrm{Ab}_{7}\right)$ of group II showed 100 per cent similarity based on molecular basis.
\end{abstract}

How to view point the article : Singh, Mahesh and Singh, H.K. (2019). Pathogenic and molecular variability among Brassica isolates of Alternaria brassicae collected from different agroclimatic regions of India. Internat. J. Plant Protec., 12(2) : 176-182, DOI : 10.15740/HAS/IJPP/ 12.2/176-182, Copyright@ 2019: Hind Agri-Horticultural Society. 